\title{
Pengetahuan Akseptor tentang KB Suntik 3 Bulan Tidak Berhubungan dengan Ketepatan Waktu Kunjungan Ulang di BPRB Bina Sehat Kasihan, Bantul, Yogyakarta
}

\author{
Sri Lestari ${ }^{1}$, Susiana Sariyati ${ }^{2}$, Wahyuningsih ${ }^{3}$ \\ 1,2,3 Sekolah Tinggi Ilmu Kesehatan Alma Ata Yogyakarta \\ Jalan Ringroad Barat Daya No 1 Tamantirto, Kasihan, Bantul, Yogyakarta
}

\begin{abstract}
Abstrak
Program pelayanan Keluarga Berencana (KB) mempunyai arti penting dalam mewujudkan manusia Indonesia yang sejahtera, disamping program pendidikan dan kesehatan. Kontrasepsi suntik memiliki efektifitas yang tinggi bila penyuntikannya dilakukan secara teratur dan sesuai jadwal yang telah ditentukan. Ketepatan ibu dalam suntik KB dipengaruhi oleh faktor pengetahuan ibu tentang KB suntik dan ditunjang dengan ingatan ibu yang baik. Tingkat pengetahuan merupakan salah satu faktor yang menyebabkan akseptor memilih atau tidak memilih suatu metode kontrasepsi. Tujuan penelitian ini untuk mengetahui hubungan tingkat pengetahuan akseptor tentang kontrasepsi suntik 3 bulan dengan ketepatan waktu kunjungan ulang. Jenis penelitian adalah penelitian observasional analitik dengan rancangan cross sectional. Teknik sampling yang digunakan adalah purposive sampling. Besar sampel adalah 63 responden. Penelitian dilakukan dengan cara memberikan kuesioner kepada akseptor yang melakukan kunjungan ulang di BPRB Bina Sehat Kasihan Bantul pada bulan Juli 2014. Uji analisis yang digunakan adalah chisquare. Hasil penelitian tingkat pengetahuan akseptor KB suntik 3 bulan sebagian besar berpengetahuan tinggi sebanyak 57 responden (90,5\%). Ketepatan waktu kunjungan ulang akseptor suntik 3 bulan sebagian besar melakukan kunjungan ulang tepat waktu sebanyak 60 responden (95,2\%). Berdasarkan analisis menggunakan rumus Chi-Square test dengan taraf signifikasi 0,05 dan derajat kebebasan 1, didapatkan Chi-Square hitung adalah 0,332 atau p-value 0,565 sedangkan Chi-Square tabel adalah 3,841. Kesimpulan tidak ada hubungan antara tingkat pengetahuan akseptor tentang KB suntik 3 bulan dengan ketepatan waktu kunjungan ulang di BPRB Bina Sehat Kasihan Bantul.
\end{abstract}

Kata Kunci: kontrasepsi suntik, ketepatan, pengetahuan

\section{Knowledge of Acceptors about Three Months Injection Family Planning Had No Relationship with Promptness Revisit at BPRB Bina Sehat Kasihan, Bantul, Yogyakarta}

\begin{abstract}
Family planning (FP) program has important role in realizing Indonesian people prosperous, besides health and education program. Contraceptive injection high effectiveness if the injection carried out regularly and appropriate schedule. Promptness revisit in FP injection is influenced by acceptors knowledge about FP injection and supported with a good memory. The knowledge level is one factor that causing acceptors choosing or not a method of contraception. The purpose of this study was to know relationship between knowledge level of acceptors and three months contraception injection with promptness revisit. This study was an observational analytic with cross sectional design. Technique sampling used was purposive sampling, resulted on 63 respondents. The study was done by granting the questionnaire to acceptors who revisit at BPRB Bina Sehat Kasihan Bantul In July 2014. Test analysis used chi-square. The results showed that knowledge of acceptors family planning about 3 months injection was 57 (90.5\%) respondents in high knowledge. Timeliness revisit of acceptors 3 months injection was $60(95.2 \%)$ respondents revisit timely. According to the analysis of using formulas chi-square test with standard significance 0.05 and degrees of freedom 1 , obtained chi-square count was 0.332 or p-value 0.565 while chi-square table was 3.841. In conclusion, there was no relationship between knowledge level of acceptors family planning and 3 months injection with promptness revisit at BPRB Bina Sehat Kasihan Bantul.
\end{abstract}

Keywords: contraception injection, knowledge, promptness

Info Artikel:

Artikel dikirim pada 11 Juni 2015

Artikel diterima pada 13 Juni 2015 


\section{PENDAHULUAN}

Program pelayanan Keluarga Berencana (KB) mempunyai arti penting dalam mewujudkan manusia Indonesia yang sejahtera, disamping program pendidikan dan kesehatan. Kesadaran mengenai pentingnya kontrasepsi di Indonesia masih perlu ditingkatkan untuk mencegah terjadinya peningkatan jumlah penduduk di Indonesia pada tahun 2015(1).

Peserta KB Baru secara nasional sampai dengan bulan Agustus 2013 sebanyak 5.547.543 peserta. Dengan persentasenya adalah 2.748 .777 peserta Suntik (49,55\%), 1.458 .464 peserta Pil $(26,29 \%)$, 475.463 peserta Implant (8,57\%), 348.134 peserta IUD (7,85\%), 330.303 peserta Kondom (5,95\%), 85.137 peserta Metode Operasional Wanita (MOW) $(1,53 \%)$, dan 9.375 peserta Metode Operasional Pria (MOP) $(0,25 \%)(2)$. Berdasarkan data Provinsi yang diperoleh dari BKKBN Daerah Istimewa Yogyakarta jumlah peserta KB baru pada tahun 2013 adalah sebagai berikut: Peserta KB Suntik 2.131 (42,08\%), peserta KB IUD 1.485 (29,32\%), peserta KB Kondom $519(10,25 \%)$, Peserta KB Implant 443 (8,75\%), Peserta KB Pil 267 (5,27\%), peserta KB MOW 175 (3,46\%), dan peserta KB MOP 44 (0,87\%) PUS(2).

Umumnya akseptor lebih memilih metode kontrasepsi suntik karena praktis yaitu sederhana dan tidak perlu takut lupa. Untuk mencegah terjadinya kehamilan adalah jika dilakukan suntik KB secara tepat waktu. Ketepatan ibu dalam suntik KB dipengaruhi oleh faktor pengetahuan ibu tentang KB suntik dan ditunjang dengan ingatan ibu yang baik(3).

Dalam memilih suatu metode kontrasepsi suntik 3 bulanan, wanita harus menimbang berbagai faktor termasuk status kesehatannya, efek samping potensial suatu metode, konsekuensi terhadap kehamilan yang tidak diinginkan, besarnya keluarga yang diinginkan, kerja sama pasangan dan norma budaya, mengenal kemampuan mempunyai anak. Termasuk didalamnya adalah memakai dan menenentukan metode kontrasepsi suntik 3 bulanan. Wanita harus mempertimbangkan pengaruh metode tersebut terhadap fungsi reproduksi, sekaligus kesejahteraan umum. Wanita mungkin menganggap masalah kesehatan, terutama masalah reproduksi, berkaitan dengan metode kontrasepsi yang digunakan saat ini. Hal ini disebabkan oleh penyuluhan dan pendidikan tentang metode yang kurang memadai, sehingga mempengaruhi pengetahuan akseptor tentang kontrasepsi suntik 3 bulanan.

Oleh sebab itu informasi tentang kontrasepsi dari petugas kesehatan sangat diperlukan. Hal ini dapat dilakukan dengan mengingatkan akseptor untuk kembali tepat waktu dan melakukan kunjungan rumah terhadap akseptor yang sudah waktunya kembali suntik tetapi belum kembali suntik, selain itu akseptor juga dapat memperoleh informasi mengenai kontarasepsi dari berbagai media, misalnya koran, majalah dan internet. Informasi yang diberikan tidak hanya untuk istri tetapi juga kepada suami, karena informasi yang cukup akan menambah pengetahuan dan wawasan pasangan suami istri tersebut tentang metode kotrasepsi khususnya metode kontrasepsi suntik 3 bulanan, sehingga menimbulkan motivasi akseptor untuk datang melakukan kunjungan ulang sesuai jadwal yang telah ditentukan.

Pengetahuan adalah informasi yang telah dikombinasikan dengan pemahaman dan potensi untuk melekat dipemikiran seseorang. Pada umumnya, pengetahuan memiliki kemampuan prediktif terhadap sesuatu sebagai hasil pengenalan atas suatu pola. Informasi dan data hanya mampu untuk menginformasikan atau bahkan menimbulkan kebingungan, maka pengetahuan mampu untuk mengarahkan tindakan. Pengetahuan merupakan suatu hal yang berperan penting dalam kehidupan, pada pengetahuan terdiri dari sejumlah fakta dan teori yang memungkinkan seseorang untuk dapat memecahkan permasalahanya. Pengetahuan tersebut diperoleh baik dari pengalaman langsung maupun melalui pengalaman orang lain. Faktor ini nantinya juga yang akan dapat mempengaruhi keberhasilan program KB di Indonesia(4).

Tingkat pengetahuan merupakan salah satu faktor yang menyebabkan akseptor memilih atau tidak memilih suatu metode kontrasepsi. Pengetahuan adalah hal yang dijadikan dasar dari suatu aksi untuk memecahkan masalah dan ini merupakan hasil dari tahu setelah orang melakukan pengindraan terhadap objek tertentu. Pengetahuan itu sendiri dipengaruhi oleh faktor pendidikan formal(4). Tujuan penelitian untuk mengetahui hubungan tingkat pengetahuan akseptor tentang KB suntik 3 bulan dengan ketepatan waktu kunjungan ulang di BPRB Bina Sehat.

\section{BAHAN DAN METODE}

Jenis penelitian ini observasional analitik dengan rancangan cross sectional. Populasi dalam penelitian ini seluruh akseptor KB suntik 3 bulan selama 1 bulan di BPRB Bina Sehat yang berjumlah 169 akseptor. Subjek penelitian adalah akseptor KB suntik 3 bulan yang melakukan kunjungan ulang di BPRB Bina Sehat. Sampel dari penelitian ini adalah sebagian ibu yang menggunakan KB suntik 3 bulan di BPRB Bina Sehat. Teknik sampling yang digunakan dalam penelitian ini adalah purposive sampling. Lokasi penelitian di BPRB Bina Sehat, Kasihan, Bantul, Yogyakarta. Waktu penelitian mulai tanggal 
27 Juni-07 Juli 2014. Alat yang digunakan pada penelitian ini berupa kuesioner. Pada penelitian ini tidak dilakukan uji validitas dan uji reliabilitas karena kuesioner yang digunakan mengadopsi dari penelitian yang dilakukan oleh Suryaningsih, yang sebelumnya telah dilakukan uji validitas dan reliabilitas di Pondok Bersalin Bidan Solikhatun, Grabag Magelang pada tanggal 18 Juli 2009 sampai 30 Juli 2009 dengan jumlah sampel sebanyak 30 orang. Hasil uji validitas menyatakan bahwa dari 40 pertanyaan terdapat 8 item pertanyaan yang tidak valid, hal ini menunjukkan tingkat validitas dari kuesioner ini $80 \%$ yang berarti tingkat validitas ini dapat dikatakan baik, dikatakan baik apabila persentasenya $>50 \%$, sedangkan dikatakan kurang apabila persentasenya sebesar $50 \%(5)$. Reliabilitas setelah 8 item tersebut dibuang, naik menjadi 0,861 . Sehingga dengan nilai 0,861 kuesioner ini menjadi reliabel.

Variabel bebas dalam penelitian ini adalah tingkat pengetahuan akseptor tentang kontrasepsi suntik tiga bulan. Variabel terikat dalam penelitian ini adalah ketepatan waktu kunjungan ulang yaitu ketepatan akseptor kontrasepsi suntik tiga bulan yang melakukan penyuntikan ulang sesuai dengan tanggal yang telah ditentukan pada kartu akseptor dan minimal melakukan kunjungan ulang sebanyak 3 kali.

\section{HASIL DAN BAHASAN}

\section{Analisis Univariat}

\section{Karakteristik Responden}

Penelitian ini dilakukan pada 63 responden yang melakukan penyuntikan ulang pada bulan Juli 2014 di BPRB Bina Sehat Kasihan Bantul.

Berdasarkan Tabel 1 menunjukkan bahwa dari jumlah 63 responden mayoritas responden berumur 20-35 tahun sebanyak 48 responden $(76,2 \%)$, mayoritas responden berpendidikan sedang (SMA) yaitu sebanyak 36 orang $(57,1 \%)$, mayoritas responden sosial ekonominya <UMK (1.125.500) yaitu sebanyak 39 orang $(61,9 \%)$, mayoritas responden sebagai ibu rumah tangga sebanyak 28 orang $(44,4 \%)$, sebagian besar responden memiliki jumlah anak dengan kriteria sedang (2-4 anak) yaitu 37 responden $(58,7 \%)$, mayoritas responden mempunyai tingkat pengetahuan yang tinggi sebanyak 57 orang $(90,5 \%)$.

Setiap individu memiliki tingkat pengetahuan yang berbeda, tingkat pengetahuan ini dipengaruhi oleh tingkat pendidikan, keterpaparan informasi dan pengalaman(6). Salah satu faktor yang berpengaruh terhadap tingkat pengetahuan yaitu pendidikan formal yang pernah ditempuh. Berdasarkan hasil penelitian,
Tabel 1. Distribusi Frekuensi Karakteristik Responden di BPRB Bina Sehat Kasihan Bantul Bulan Juli 2014

\begin{tabular}{|c|c|c|}
\hline Karakteristik Responden & $f$ & $\%$ \\
\hline \multicolumn{3}{|l|}{ Umur } \\
\hline$<20$ tahun & 1 & 1,6 \\
\hline 20-35 tahun & 48 & 76,2 \\
\hline$>35$ tahun & 14 & 22,2 \\
\hline \multicolumn{3}{|l|}{ Pendidikan } \\
\hline Tinggi (Diploma/Perguruan Tinggi) & 1 & 1,6 \\
\hline Sedang (SMA/SMK) & 36 & 57,1 \\
\hline $\begin{array}{l}\text { Rendah (Tidak Tamat SD/SD atau } \\
\text { SMP) }\end{array}$ & 26 & 41,3 \\
\hline \multicolumn{3}{|l|}{ Sosial Ekonomi } \\
\hline >UMK & 24 & 38,1 \\
\hline$<$ UMK & 39 & 61,9 \\
\hline \multicolumn{3}{|l|}{ Pekerjaan } \\
\hline Buruh/Karyawan & 23 & 36,5 \\
\hline Dagang & 2 & 3,2 \\
\hline IRT & 28 & 44,4 \\
\hline Swasta & 8 & 12,7 \\
\hline Wiraswasta & 2 & 3,2 \\
\hline \multicolumn{3}{|l|}{ Jumlah Anak } \\
\hline Banyak (>5) & 0 & 0 \\
\hline Sedang (2-4) & 37 & 58,7 \\
\hline Sedikit (0-1) & 26 & 41,3 \\
\hline \multicolumn{3}{|l|}{ Tingkat Pengetahuan } \\
\hline Tinggi & 57 & 90,5 \\
\hline Sedang & 6 & 9,5 \\
\hline Rendah & 0 & 0 \\
\hline Total & 63 & 100 \\
\hline
\end{tabular}

Sumber: Data Primer Tahun 2014

pendidikan responden yang paling banyak adalah tamatan SMA/SMK yaitu 36 orang $(57,1 \%)$, sedangkan yang paling sedikit adalah yang berpendidikan tinggi (Diploma/Perguruan Tinggi) sebanyak 1 orang (1,6\%). Akseptor yang memiliki tingkat pendidikan lebih tinggi ternyata belum menjamin akseptor tersebut bersikap sesuai tingkat pengetahuan yang dimiliki.

Menurut Istiarti, ibu yang memiliki pendidikan dan pengetahuan yang luas, akan memiliki wawasan yang luas pula, sehingga akan berfikir positif dan akan melakukan penyuntikan ulang tepat waktu sesuai dengan kesadaran pribadinya(7). Tetapi pendidikan bukanlah satu-satunya faktor yang mempengaruhi perilaku seseorang. Perilaku dipengaruhi oleh faktor eksternal yang secara langsung dapat mempengaruhi perubahan pola pikir yang positif yang diberikan orang lain untuk terjadi perubahan perilaku. Artinya responden yang mempunyai pengetahuan baik belum tentu mempunyai perilaku yang baik demikian juga sebaliknya.

Faktor yang mempengaruhi terhadap tingkat pengetahuan selain pendidikan adalah keterpaparan informasi. Irmayanti menyatakan bahwa informasi 
dapat digunakan sebagai transfer pengetahuan. Informasi dapat diperoleh dalam kehidupan seharihari melalui media massa antara lain televisi, koran, radio, dan majalah(6). Informasi yang jelas dari tenaga kesehatan atau sumber informasi yang lain memberikan pengetahuan yang jelas tentang KB suntik.

Selain informasi pengalaman juga merupakan salah satu faktor yang mempengaruhi tingkat pengetahuan seseorang. Pengalaman merupakan sumber pengetahuan atau pengalaman itu merupakan suatu cara untuk memperoleh kebenaran pengetahuan(4). Semakin banyak pengalaman seseorang maka pengetahuannya juga akan bertambah. Belajar dari pengalaman merupakan suatu proses yang dapat mengubah sikap dan tingkah laku kita(8). Seseorang cenderung menerapkan pengalamannya terdahulu untuk memecahkan masalah yang dihadapinya.

Pengalaman yang dimiliki oleh responden menyebabkan seseorang mempunyai kemampuan analisis dan sintesis yang baik. Pengalaman mempengaruhi pengetahuan tentang KB suntik. Pengalaman akseptor tentang KB suntik berasal dari pengalaman pribadi atau pengalaman akseptor lain.

Penelitian ini sesuai dengan penelitian Prasetyawati, dkk bahwa pengalaman merupakan salah satu faktor yang mempengaruhi tingkat pengetahuan seseorang(9). Pengalaman yang dimilki responden menyebabkan seseorang mempunyai kemampuan analisis dan sintesis yang baik.

\section{Ketepatan Waktu Kunjungan Ulang di BPRB Bina Sehat Bulan Juli 2014}

Distribusi frekuensi tingkat ketepatan rsponden tentang waktu kunjungan ulang di BPRB Bina Sehat bulan Juli tahun 2014 dibagi atas tepat dan tidak tepat.

Tabel 2. Distribusi Frekuensi Tingkat Ketepatan Responden tentang Waktu Kunjungan Ulang di BPRB Bina Sehat Bulan Juli 2014

\begin{tabular}{ccc}
\hline Ketepatan & f & \% \\
\hline Tepat & 60 & 95,2 \\
Tidak tepat & 3 & 4,8 \\
Total & 63 & 100 \\
\hline
\end{tabular}

Sumber: Data Primer 2014

Berdasarkan Tabel 2 dari 63 responden yang melakukan kunjungan ulang didapatkan 60 responden $(95,2 \%)$ tepat dalam melakukan penyuntikan ulang sesuai jadwal sedangkan sebanyak 3 responden
$(4,8 \%)$ tidak tepat dalam melakukan penyuntikan ulang sesuai jadwal.

Pada kartu KB dapat dilihat ketepatan waktu untuk suntik ulang pada kunjungan kedua dan seterusnya. Dikatakan tepat waktu apabila dalam melakukan kunjungan ulang untuk suntik kembali akseptor KB suntik 3 bulan belum melampaui batas waktu selama satu minggu dari 12 minggu. Ketepatan waktu untuk suntik kembali merupakan kepatuhan akseptor karena bila tidak tepat dapat mengurangi efektifitas kontrasepsi tersebut. Kegagalan dari metode kontrasepsi suntik disebabkan karena keterlambatan akseptor untuk melakukan penyuntikan ulang.

Berdasarkan dari 3 orang yang dilakukan wawancara tentang alasan kenapa tidak tepat waktu dalam kunjungan ulang suntik KB 3 bulan 1 orang diantaranya menjawab alasannya karena akseptor lupa jadwal kapan untuk melakukan suntik kembali. Saat penelitian telah dilakukan wawancara mengenai ketidaktepatan waktu suntik kembali. Ibu mengatakan tidak memperhatikan jadwal yang telah diberikan oleh petugas dalam kartu KB dalam melakukan penyuntikan ulang. Dua orang yang lainnya mengatakan alasan tidak tepat waktu dalam penyuntikan ulang karena kesibukan akan pekerjaan sehari-hari. Akseptor berasal dari berbagai golongan masyarakat yang memiliki pekerjaan bermacammacam. Pekerjaan dapat menyita waktu, sehingga tidak memungkinkan pergi ke BPRB Bina Sehat untuk melakukan suntik kembali. Perilaku seseorang dalam mematuhi setiap anjuran dari tenaga kesehatan dipengaruhi oleh beberapa faktor antara lain: tingkat pengetahuan, tingkat pendidikan, sosial ekonomi, dan pekerjaan. Selain itu juga fasilitas pelayanan kesehatan, sikap dan perilaku petugas kesehatan juga mendukung dan memperkuat terbentuknya perilaku seseorang.

Faktor lain yang mempengaruhi ketepatan KB adalah pendidikan. Berdasarkan teori bahwa makin tinggi tingkat pendidikan seseorang makin mudah menerima informasi sehingga makin banyak pula pengetahuan yang dimiliki(10). Sebaliknya pendidikan yang kurang akan menghambat perkembangan sikap seseorang terhadap nilai-nilai yang baru diperkenalkan(11). Seseorang yang berpendidikan tinggi akan mudah dalam menyerap informasi untuk melakukan penyuntikan sesuai jadwal yang ditentukan.

Faktor pekerjaan juga mempengaruhi ketepatan waktu kunjungan suntik KB 3 bulan, dengan adanya pekerjaan, seseorang akan memerlukan banyak waktu dan tenaga untuk menyelesaikan pekerjaan yang dianggap penting dan memerlukan perhatian(11). 
Seorang wanita yang telah memasuki lapangan kerja, mereka dengan sendirinya mengurangi waktunya untuk mengurus rumah, balita bahkan suaminya. Sehingga hal ini menyebabkan ibu tidak bisa melakukan penyuntikan ulang KB sesuai waktu yang telah ditentukan. Dalam penelitian ini data menunjukkan akseptor yang tidak tepat cenderung karena kesibukan, terikat dengan jam kerja dan kesibukan yang banyak. Pekerjaan memerlukan waktu dan tenaga untuk menyelesaikan berbagai jenis pekerjaan masing-masing dianggap penting dan memerlukan perhatian dan waktu(12). Ada kesesuaian antara teori dan hasil penelitian, bahwa pekerjaan memerlukan waktu yang banyak sehingga mengganggu ketepatan waktu suntik kembali.

Penelitian ini sesuai dengan penelitian Handayani bahwa pekerjaan mempengaruhi ketidaktepatan suntik KB 3 bulan. Handayani mengungkapkan bahwa akseptor yang bekerja cenderung tidak tepat dalam suntik kembali karena faktor kesibukan(13).

Dalam penelitian ini faktor sosial ekonomi tidak mempengaruhi ketepatan kunjungan ulang, berdasarkan data akseptor yang berpenghasilan $<$ UMK (Rp 1.125.500) adalah yang paling banyak dan melakukan kunjungan ulang tepat waktu. Berbeda dengan penelitian Handayani bahwa keluarga yang berpenghasilan di bawah $\leq 900.000$ termasuk keluarga miskin dan lebih mementingkan keperluan lain yang lebih prioritas dibandingkan suntik kembali, sehingga banyak akseptor yang tidak tepat dalam penyuntikan kembali(13).

\section{Analisis Bivariat}

Hasil tabulasi silang antara tingkat pengetahuan akseptor tentang KB suntik 3 bulan dengan ketepatan waktu kunjungan ulang di BPRB Bina Sehat dapat dilihat pada Tabel 3.

Berdasarkan hasil penelitian pada Tabel 3, jumlah responden yang paling banyak adalah responden yang memiliki tingkat pengetahuan yang tinggi dan tepat untuk melakukan kunjungan ulang ulang sesuai jadwal yaitu sebanyak 54 responden
$(85,7 \%)$, sedangkan jumlah responden yang paling sedikit yaitu responden yang memiliki tingkat pengetahuan tinggi dan tidak tepat melakukan kunjungan ulang sesuai jadwal sebanyak 3 responden $(4,8 \%)$.

Responden yang berpengetahuan sedang adalah 6 responden $(9,5 \%)$ yang melakukan kunjungan ulang untuk suntik kembali dengan tepat waktu dan tidak ada yang tidak tepat waktu. Berdasarkan hasil penelitian tidak ada yang berpengetahuan rendah. Sebagian besar responden berpengetahuan tinggi tentang KB suntik 3 bulan, dikarenakan penelitian yang dilakukan mengukur tingkat pengetahuan responden pada saat ini dan bukan tingkat pengetahuan pada saat Iampau atau sebelum menggunakan KB suntik 3 bulan. Hal ini sesuai dengan pendapat yang dikemukakan oleh Notoatmodjo mengenai faktor-faktor yang mempengaruhi pengetahuan(12). Menurut Notoatmodjo, pengetahuan adalah hasil tahu, dan ini terjadi setelah orang melakukan penginderaan terhadap suatu objek tertentu(14). Notoatmodjo mengatakan bahwa pengalaman pribadi akan memberi kesempatan kepada seseorang untuk memiliki pengetahuan dan tanggapan atas suatu objek(12). Ada 3 responden (4,8\%) yang berpengetahuan tinggi namun tidak melakukan kunjungan ulang tepat waktu dan 6 responden $(9,5 \%)$ yang berpengetahuan sedang namun melakukan kunjungan ulang tepat waktu. Hal ini berarti untuk melakukan kunjungan ulang dengan tepat waktu tidak harus selalu memilki pengetahuan yang tinggi, namun dapat pula dipengaruhi oleh faktor-faktor lain. Misalnya, jenis pekerjaan yang akan mempengaruhi waktu, status sosial ekonomi yang berpengaruh terhadap kemampuan akseptor untuk membayar, serta tersedianya fasilitas pelayanan kesehatan(12).

Pengetahuan mempunyai pengaruh dalam membentuk perilaku seseorang dan ketepatan waktu suntik KB adalah proses penerimaan seseorang terhadap respon tindakan atau perbuatan, dimana proses ini didasari oleh pengetahuan, kesadaran dan sikap yang mempunyai dampak pada perilaku yang bersifat langgeng. Sebaliknya apabila perilaku

Tabel 3. Hubungan Tingkat Pengetahuan Akseptor tentang KB Suntik 3 Bulan dengan Ketepatan Waktu Kunjungan Ulang

\begin{tabular}{|c|c|c|c|c|c|c|c|c|}
\hline \multirow{3}{*}{$\begin{array}{c}\text { Tingkat } \\
\text { Pengetahuan }\end{array}$} & \multicolumn{4}{|c|}{ Ketepatan Waktu Kunjungan Ulang } & \multirow{2}{*}{\multicolumn{2}{|c|}{ Total }} & \multirow{3}{*}{$\begin{array}{c}\text { Chi- } \\
\text { Square }\end{array}$} & \multirow{3}{*}{$p$-value } \\
\hline & \multicolumn{2}{|c|}{ Tepat } & \multicolumn{2}{|c|}{ Tidak Tepat } & & & & \\
\hline & f & $\%$ & f & $\%$ & f & $\%$ & & \\
\hline Tinggi & 54 & 85,7 & 3 & 4,8 & 57 & 90,5 & \multirow{4}{*}{0,332} & \multirow{4}{*}{0,565} \\
\hline Sedang & 6 & 9,5 & 0 & 0 & 6 & 9,5 & & \\
\hline Rendah & 0 & 0 & 0 & 0 & 0 & 0 & & \\
\hline Total & 60 & 95,2 & 3 & 4,8 & 63 & 100 & & \\
\hline
\end{tabular}

Sumber: Data Primer Tahun 2014 
tidak didasari oleh pengetahuan dan kesadaran akan tidak berlangsung lama(15). Sehingga pengetahuan merupakan domain yang sangat penting dalam membentuk tindakan seseorang dalam hal ini adalah ketepatan waktu untuk melakukan penyuntikan ulang sesuai jadwal. Apabila tingkat pengetahuan akseptor tentang KB suntik 3 bulan tinggi maka akseptor akan mempunyai kesadaran untuk melakukan suntik ulang tepat waktu.

Faktor yang lainnya adalah tingkat pendidikan. Semakin tinggi pendidikan akseptor maka semakin mudah bagi akseptor untuk menyerap informasi tentang KB suntik 3 bulan. Berdasarkan teori bahwa makin tinggi tingkat pendidikan seseorang makin mudah menerima informasi sehingga makin banyak pula pengetahuan yang dimiliki(10). Sebaliknya pendidikan yang kurang akan menghambat perkembangan sikap seseorang terhadap nilainilai yang baru diperkenalkan(11). Seseorang yang berpendidikan tinggi akan mudah dalam menyerap informasi untuk melakukan penyuntikan sesuai jadwal yang ditentukan.

Faktor lainnya adalah pekerjaan, pekerjaan yang banyak menyita waktu akan menyebabkan akseptor tidak sempat untuk melakukan kunjungan ulang tepat waktu dikarenakan kesibukan yang tidak bisa ditinggalkan dengan adanya pekerjaan, seseorang akan memerlukan banyak waktu dan tenaga untuk menyelesaikan pekerjaan yang dianggap penting dan memerlukan perhatian(11). Seorang wanita yang telah memasuki lapangan kerja, mereka dengan sendirinya mengurangi waktunya untuk mengurus rumah, balita bahkan suaminya. Sehingga hal ini menyebabkan ibu tidak bisa melakukan penyuntikan ulang KB sesuai waktu yang telah ditentukan. Dalam penelitian ini data menunjukkan akseptor yang tidak tepat cenderung karena kesibukan, terikat dengan jam kerja dan kesibukan yang banyak. Pekerjaan memerlukan waktu dan tenaga untuk menyelesaikan berbagai jenis pekerjaan masing-masing dianggap penting dan memerlukan perhatian dan waktu(12). Ada kesesuaian antara teori dan hasil penelitian, bahwa pekerjaan memerlukan waktu yang banyak sehingga mengganggu ketepatan waktu suntik kembali.

Faktor yang lain adalah status sosial ekonomi yang baik akan menyebabkan akseptor mempunyai uang untuk melakukan suntik kembali dengan tepat waktu. Faktor yang mendukung adalah tersedianya fasilitas pelayanan kesehatan dan keterampilan para petugas kesehatan, dalam hal ini yaitu BPRB Bina Sehat Kasihan, Bantul, Yogyakarta yang menyediakan pelayanan KB.

Berdasarkan hasil penelitian menunjukkan bahwa tidak ada hubungan antara tingkat pengetahuan akseptor tentang kontrasepsi suntik 3 bulan dengan ketepatan waktu kunjungan ulang. Hal ini dibuktikan dengan hasil uji statistik dengan menggunakan rumus chi-square dengan tingkat kepercayaan 0,05 (5\%) diperoleh nilai chi-square hitung $(0,332)$ atau $p$-value 0,565 . Nilai chi-square tersebut jika dibandingkan dengan nilai chi-square tabel $(3,841) 5 \%$ maka dapat disimpulkan bahwa nilai chi-square hitung $(0,332)$ atau $p$-value $0,565<$ nilai chi-square tabel $(3,841) 5 \%$. Dari hasil tersebut dapat disimpulkan bahwa $\mathrm{H} 0$ diterima dan Ha ditolak sehingga tidak ada hubungan antara tingkat pengetahuan akseptor tentang kontrasepsi suntik 3 bulan dengan ketepatan waktu kunjungan ulang. Hipotesis tersebut tidak sesuai dengan teori yang menyebutkan bahwa tingkat pengetahuan tentang KB suntik 3 bulan dapat menyebabkan akseptor KB suntik 3 bulan tepat dalam melakukan kunjungan ulang. Jadi pengetahuan seseorang tidak mempengaruhi ketepatan untuk melakukan penyuntikan ulang sesuai jadwal. Akseptor yang berpengetahuan tinggi ternyata tidak tepat saat melakukan suntik kembali. Faktor lain yang memungkinkan dari penelitian ini karena kesibukan dimana ketika peneliti melakukan penelitian bertepatan dengan hari puasa sehingga banyak akseptor yang sibuk untuk menyiapkan buka puasa dan terawih sehingga ketika responden mengisi kuesioner yang dibagikan responden tergesa-gesa dalam menjawabnya yang memungkinkan responden tidak menjawab dengan membacanya secara seksama. Hal ini dapat menyebabkan kuesioner yang telah dijawab tidak sesuai dengan kenyataannya atau tidak sesuai pengetahuan yang sebenarnya.

Hasil penelitian ini sesuai dengan penelitian Handayani yang memperoleh hasil bahwa waktu suntik kembali dan pengetahuan tidak memiliki hubungan yang signifikan dengan nilai chi-square hitung $(3,974)<$ chi-square tabel $(5,991)$ atau nilai probalitas pada penelitian Handayani $0,137(>0,05)$, untuk responden sebanyak 38 akseptor(13).

Hasil penelitian ini berbeda dengan penelitian Pujiati dimana ada hubungan yang signifikan antara tingkat pengetahuan tentang kontrasepsi suntik dengan kepatuhan jadwal penyuntikan ulang. Hasil uji statistik diperoleh nilai $\chi^{2}$ hitung sebesar $6,614>\chi^{2}$ tabel $=3,841$ dan nilai $p$-value $=0,024(16)$. Hasil penelitian ini berbeda dengan penelitian Prasetyawati, dkk dimana pengetahuan mempengaruhi kepatuhan dalam mengkonsumsi pil KB(9). Hasil uji statistik diperoleh nilai chi-square sebesar 6,451 yang lebih besar dari $\chi^{2}$ tabel yaitu 3,481 dan nilai $p$-value $=0,011$ yang lebih kecil dari 0,05 , artinya ada hubungan yang signifikan antara pengetahuan akseptor tentang pil oral kombinasi dengan kepatuhan dalam mengkonsumsi pil KB. 


\section{SIMPULAN DAN SARAN}

Karakteristik responden yang dilihat dari karakteristik umur sebagian besar responden berumur 20-35 tahun sebanyak 48 responden $(76,2 \%)$. Berdasarkan karakteristik pendidikan responden terbanyak berpendidikan sedang (SMA/SMK) sebanyak 36 responden $(57,1 \%)$. Berdasarkan karakteristik pekerjaan sebagian besar bekerja sebagai ibu rumah tangga sebanyak 28 responden $(44,4 \%)$. Berdasarkan karakteristik sosial ekonomi sebagian besar berpenghasilan <UMK (1.125.500) yaitu sebanyak 39 responden $(61,9 \%)$. Berdasarkan karakteristik jumlah anak sebagian besar responden memiliki anak dengan kriteria 2-4 anak sebanyak 37 responden (58,7\%). Tingkat pengetahuan Akseptor tentang KB suntik 3 bulan di BPRB Bina Sehat sebagian besar responden memiliki pengetahuan yang tinggi yaitu sebanyak 57 responden (90,5\%). Ketepatan waktu kunjungan ulang suntik KB 3 bulan di BPRB Bina Sehat sebagian besar melakukan kunjungan ulang secara tepat waktu sebanyak 60 responden $(95,2 \%)$.

Mengingat ketepatan waktu untuk suntik ulang sangat berpengaruh terhadap keberhasilan KB suntik bulan, maka diharapkan akseptor akan mempunyai motivasi yang lebih tinggi untuk melakukan suntik ulang dengan tepat waktu.

\section{RUJUKAN}

1. BKKBN. Keluarga Berencana dan Kesehatan Reproduksi: Kontrasepsi dan Fenomena Keluarga Bahagia [internet]. 2008 [cited 2014 Februari 02]. Available from: http://www.bkkbn.go.id.

2. BKKBN. Pelayanan Kontrasepsi: Hasil Pelayanan Peserta KB Baru Menurut Metode Kontrasepsi Tahun 2013 [internet]. 2013 [cited 2014 Februari 02]. Available from: http://www.bkkbn.go.id.

3. BKKBN. Revitalisasi Program KB Mendesak. Jakarta [internet]. 2007 [cited 2014 Februari 03]. Available from: http://www.bkkbn.go.id.

4. Notoadmodjo S. Metode Penelitian Kesehatan. Jakarta: Rineka Cipta; 2010.
5. Suryaningsih ID. Hubungan Tingkat Pengetahuan Akseptor KB Suntik 3 bulan dengan Ketepatan waktu Kunjungan Ulang di Puskesmas Grabag I Magelang Jateng. Stikes Alma Ata Yogyakarta; 2009.

6. Irmayanti. Pengetahuan [internet]. 2007 [cited 2014 Februari 03]. Available from: http.//. id.wikipedia.org/wiki/pengetahuan.

7. Istiarti T. Menanti Buah Hati Antara Kemiskinan dan Kesehatan. Yogyakarta: Pressindo; 2004.

8. Purwanto, Ngalim. Psikologi Pendidikan. Bandung: Remaja Rosda Karya; 2004.

9. Prasetyawati, et al. Hubungan Pengetahuan Akseptor Tentang Kontrasepsi Pil Oral Kombinasi dengan Kepatuhan dalam Mengkonsumsi Pil KB di Wilayah Desa Margasana Kecamatan Jatilawang Tahun 2012. J IImu Kebidanan. 2012;3(2).

10. Nursalam. Proses dan Dokumentasi Keperawatan, Konsep dan Praktik. Jakarta: Salemba Medika; 2001.

11. Nursalam, Pariani S. Pendekatan Praktis Metodologi Riset Keperawatan. Jakarta: CV. Sagung Seto; 2001.

12. Notoadmodjo S. Pendidikan dan Perilaku Kesehatan. Jakarta: Rineka Cipta; 2003.

13. Handayani RD. Faktor-Faktor Yang Mempengaruhi Ketepatan Waktu Suntik Kembali Bagi Akseptor KB Suntik 3 Bulan Di Puskesmas Sidorejo Lor Salatiga. Program Studi IImu Keperawatan Fakultas IImu Kesehatan Universitas Kristen Satya Wacana Salatiga; 2012.

14. Notoadmodjo S. Promosi Kesehatan dan IImu Perilaku. Jakarta: Rineka Cipta; 2007.

15. Budioro. Ilmu Kesehatan Masyarakat. Jakarta: Raja Grafido Persada; 2002.

16. Pujiati N. Hubungan Tingkat Pengetahuan Tentang Kontrasepsi DMPA dengan Kepatuhan Jadwal Penyuntikan Ulang di Rumah Bersalin AnNissa Surakarta. Surakarta: Universitas Sebelas Maret Surakarta Jurusan Kebidanan Fakultas Kedokteran; 2009. 